\title{
Qualidade fisico-química de hortaliças folhosas comercializadas no município de Jaboticabal-SP ${ }^{1}$
}

\author{
Jonathan dos Santos Viana ${ }^{2}$, Thayane Leonel Alves ${ }^{2}$, Maria do Socorro Nahuz Lourenço ${ }^{3}$, Luiz \\ Fabiano Palaretti ${ }^{4}$
}

\begin{abstract}
Resumo: As hortaliças são alimentos reguladores, importante para o bom funcionamento do organismo. Objetivou-se neste trabalho determinar a caracterização físico-química de hortaliças folhosas comercializadas em supermercados do município de Jaboticabal - São Paulo. As hortaliças tipo folha "couve, almeirão e chicória" analisadas no presente trabalho, foram adquiridas em dois supermercados do município de Jaboticabal e encaminhadas ao laboratório de biomassa I, UNESP - FCAV, Câmpus de Jaboticabal-SP, onde foram realizadas as seguintes análises: $\mathrm{pH}$, acidez titulável, cinzas, umidade, teor de nitrogênio e proteína. O almeirão apresentou maior teor de umidade com $94,74 \%$, seguido da couve e chicória, com $88,81 \%$ e $82,28 \%$, respectivamente. Os valores de cinzas, acidez titulável, nitrogênio e proteínas das hortaliças, apresentaram percentuais satisfatórios. Entretanto, apesar dos teores dos componentes físico-químicos está dentro dos padrões estabelecidos na tabela brasileira de composição de alimentos, cabe ao consumidor de hortaliças, fazer a aquisição das mesmas, levando em consideração a data da comercialização, os aspectos da aparência global e a forma em que as mesmas se encontram armazenadas.
\end{abstract}

Palavras-chave: Análises físico-químicas; Formas de venda; Olerícolas.

\section{Physical-chemical quality of leafy vegetables commercialized in the municipality of Jaboticabal-SP}

\begin{abstract}
Vegetables are regulating foods, important for the proper functioning of the organism. The objective of this work was to determine the physical-chemical characterization of leafy vegetables sold in supermarkets in the municipality of Jaboticabal - São Paulo. The leaf type vegetables "cabbage, almond and chicory" analyzed in the present work, were acquired in two supermarkets in the municipality of Jaboticabal and sent to the biomass laboratory I, UNESP - FCAV, Câmpus de Jaboticabal-SP, where the following analyzes were carried out: pH, titratable acidity, ash, moisture, nitrogen and protein content. The almond presented the highest moisture content with $94.74 \%$, followed by cabbage and chicory, with $88.81 \%$ and $82.28 \%$, respectively. The values of ash, titratable acidity, nitrogen and protein of vegetables, presented satisfactory percentages. However, despite the contents of the physical-chemical components it is within the standards established in the Brazilian table of food composition, it is up to the consumer of vegetables, make the purchase of them, taking into account the date of commercialization, the aspects of global appearance and the the way in which they are stored.
\end{abstract}

Keywords: Physicochemical analysis; Forms of sale; Vegetables.

\footnotetext{
${ }^{1}$ Submetido em 23/03/2020 e aprovado em 09/12/2020;

${ }^{2}$ Universidade Estadual Paulista, Programa de Pós Graduação em Agronomia (Ciência do Solo), Jaboticabal, São Paulo, Brasil; E-mail: jonathan.viana@unesp.br (Autor correspondente) - ORCID: https://orcid.org/0000-0003-4734-9843; thayaneleonel@hotmail.com - ORCID: https://orcid.org/0000-0003-3532-2117;

${ }^{3}$ Universidade Estadual do Maranhão, Departamento de Química, São Luís, Maranhão, Brasil; E-mail: snahuz@hotmail.com - ORCID: https://orcid.org/0000-0001-9176-242X;

${ }^{4}$ Universidade Estadual Paulista, Departamento de Engenharia e Ciências Exatas, Jaboticabal, São Paulo, Brasil; E-mail: lfpalaretti@fcav.unesp.br - ORCID: https://orcid.org/0000-0001-5107-6038
}

Agropecuária Técnica, Areia-PB, v. 41, n. 3-4, p. 92-100, 2020 


\section{Introdução}

O consumo de hortaliças folhosas é de fundamental importância, em qualquer dieta alimentar, principalmente, em função, do seu aporte nutricional, como, fibras dietéticas, sais minerais, vitaminas e baixo valor calórico, além de prevenir o risco de desenvolver as doenças não transmissíveis, como, as cardiovasculares, diabetes, obesidade e alguns tipos de câncer. Em função disso, os consumidores de hortaliças, estão cada vez mais procurando qualidade e diversidade, além de praticidade dos produtos ofertados, que tornam o seu dia a dia mais prático, e dentro deste contexto, os alimentos in natura e/ou minimamente processados são uma ótima opção para a população (Santos et al., 2019).

As hortaliças folhosas são comercializadas in natura ou minimamente processadas e devem sempre ser ofertadas ao consumidor com qualidade e com segurança alimentar (Henrique et al., 2019). No Brasil, os alimentos minimamente processados começaram a ser comercializados por volta de 1990, apresentando como facilidade ao consumidor o fato de já estarem pronto ao consumo e portanto, não apresentarem a necessidade de lavar, cortar e preparar esses alimentos, assim, eles foram muito bem aceitos pelos consumidores (Silva et al., 2018).

De acordo com Dalastra et al. (2019), os produtos minimamente processados são hortaliças ou frutas manipuladas fisicamente, facilitando a vida do consumidor, elas são lavadas, selecionadas, cortadas e embaladas, oferecendo ao consumidor utilidade e qualidade de produto. Dentre as vantagens que os produtos minimamente processados trazem estão diminuição de tempo de preparo dos alimentos, de desperdícios, e de espaço para armazenagem, e maior padronização e qualidade (Cenci, 2000). Já as desvantagens estão na perecibilidade dos alimentos, já que foram submetidos a algum tipo de processamento, como, corte, trituração e outros danos físicos, o que ocasiona o aumento do metabolismo e consequentemente, da taxa respiratória e síntese de etileno, acelerando sua deterioração (Vitti et al. 2004).

A couve é comercializada em supermercados tanto na forma in natura como minimamente processadas, sendo uma hortaliça muita rica em nutrientes, especialmente cálcio, ferro, vitaminas
A, C, K e B5, além de ser considerada boa fonte de carotenoides, apresentando entre as hortaliças, maiores concentrações de luteína e beta caroteno, nutrientes que comprovadamente, reduzem os riscos de desenvolver câncer no pulmão e de doenças oftalmológicas crônicas como a catarata (Lefsrud, 2007). O almeirão, é uma planta herbácea, de ciclo anual, muito semelhante a chicória-amarga, devido seu sabor amargo. É considerada como relevante fonte nutricional de fitoquímicos e possui boa aceitabilidade pelos consumidores do município de Jaboticabal - SP. A chicória, é uma hortaliça da família das quenopodiáceas, também consumida no Brasil, com grande aceitabilidade nas regiões sul, sudeste e centro oeste (Gonsalves, 2009). Dessa hortaliça, pode ser consumido as folhas e os talos em saladas ou refogados. A planta de chicória é constituída por cerca de $90 \%$ de água, 5,5\% de hidratos de carbono, $1,5 \%$ de proteínas, vitaminas "A, C e do complexo B", além de minerais, como: "cálcio, fósforo, sódio, potássio, magnésio, cloro, enxofre e ferro" (Gonsalves, 2009). Pode ser consumida crua, em saladas, e refogada como a couve. É vendida em maços, e os caules podem ser consumidos fritos ou cozidos em sopas (Godin, 2010).

Pereira et al. (2016), determinando a qualidade físico-química das hortaliças folhosas in natura da couve, chicória e alface constataram percentuais adequados de qualidade físico-química póscolheita para essas hortaliças comercializadas no Brejo Paraibano.

Em função da importância alimentar e nutricional das hortaliças, do aumento no consumo e da busca constante do consumidor pela qualidade das mesmas, objetivou-se com esta pesquisa fazer uma caracterização físico-química das hortaliças folhosas "couve, almeirão e chicória" comercializadas em supermercados do município de Jaboticabal - São Paulo.

\section{Material e métodos}

\subsection{Descrição do local e aquisição das amostras}

O experimento foi conduzido no Laboratório Biomassa I, pertencente ao Departamento de Engenharia e Ciências Exatas, FCAV - Câmpus Jaboticabal. Amostras de três hortaliças folhosas, couve, almeirão e chicória, minimamente processadas (Figuras 1 e 2) e in natura, foram adquiridas em supermercados localizados no município de Jaboticabal, estado de São Paulo.

Agropecuária Técnica, Areia-PB, v. 41, n. 3-4, p. 92-100, 2020

https://doi.org/10.25066/agrotec.v41i3-4.51299 
a)

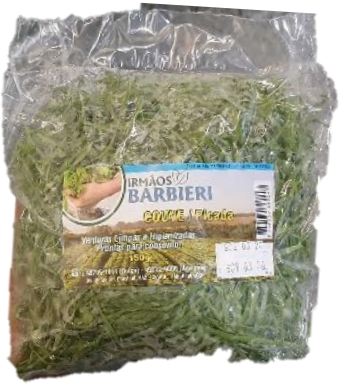

b)

c)

Figura 1 Formas de venda das hortaliças folhosas couve (a), chicória (b) e almeirão (c) minimamente processadas, comercializadas no Supermercado A. Jaboticabal, UNESP, 2019.

a)

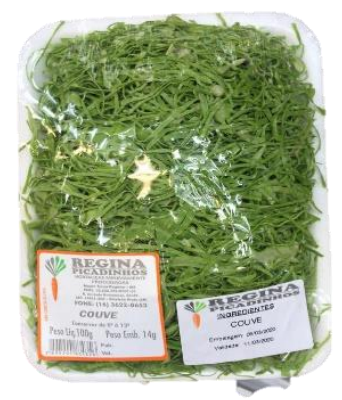

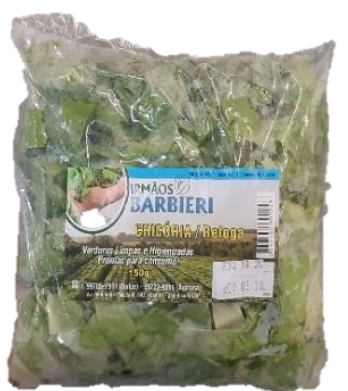

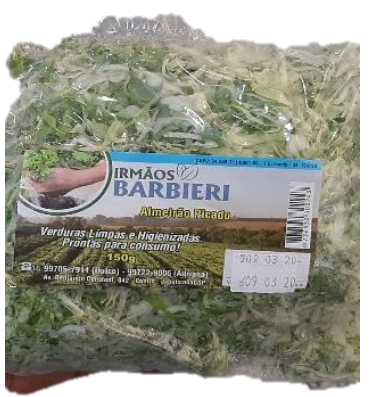

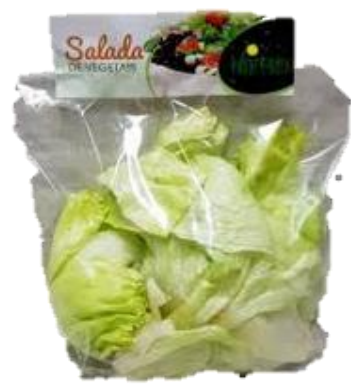

b)

c)

Figura 2 Formas de venda das hortaliças folhosas couve (a), chicória (b) e almeirão (c) minimamente processadas, comercializadas no Supermercado B. Jaboticabal, UNESP, 2019.

O delineamento experimental utilizado foi em blocos inteiramente casualizados (DIC), constituídos de esquema fatorial $2 \times 2$, sendo duas formas de comercialização (hortaliças folhosas minimamente processadas e in natura) coletadas em dois supermercados do município, em 4 repetições. Cada repetição constituiu da aquisição de 3 hortaliças por espécie/supermercado.

\subsection{Pré-tratamento das amostras}

As etapas de pré-tratamento, identificação e acondicionamento das amostras foram feitas de acordo com o Manual de Análises Químicas de Solos, Plantas e Fertilizantes (Embrapa, 2009). As amostras de hortaliças folhosas in natura adquiridas foram acondicionadas em sacos PVC transparentes de $100 \mathrm{~g}$, com pequenas perfurações, já as hortaliças minimamente processadas foram deixadas nos próprios recipientes nos quais foram adquiridas, sendo posteriormente, armazenadas em refrigerador até o momento das análises.

As amostras foram identificadas, por meio de numeração e seguiram para a etapa de limpeza e sanitização, onde além da lavagem inicial com água foi realizada uma lavagem com solução de ácido clorídrico a $3 \%$ com posterior enxágue com água destilada. A descontaminação foi realizada para retirar os possíveis resíduos decorrentes de adubação foliar com produtos contendo zinco, molibdênio e boro.

\subsection{Análise físico-químicas}

\section{$2.3 .1 \mathrm{pH}$}

Foram pesados $10 \mathrm{~g}$ da amostra de cada hortaliça em um béquer que passou por trituração em liquidificador doméstico com adição de 100 $\mathrm{mL}$ de água destilada. Após trituração, a amostra foi agitada e deixada em repouso por 10 minutos 
(Instituto Adolfo Lutz, 2008). A leitura do $\mathrm{pH}$ foi realizada com aparelho previamente calibrado.

\subsubsection{Acidez titulável}

As medidas de acidez titulável (AT), expressa em percentagem de ácido cítrico, foram realizadas por titulação com solução de $\mathrm{NaOH} \quad 0,1 \mathrm{~N}$, previamente padronizada, conforme Manual de Análises Químicas de Solos, Plantas e fertilizantes (EMBRAPA, 1999). As amostras das hortaliças foram trituradas com água destilada, em liquidificador doméstico, na proporção de 1:2. A seguir, procedeu-se a titulação de 10 $\mathrm{mL}$ da amostra triturada com adição de $50 \mathrm{~mL}$ de água destilada e três gotas de fenolftaleína alcoólica a $1,0 \%$.

\subsubsection{Cinzas}

Foi pesado $10 \mathrm{~g}$ da amostra em cápsula de porcelana. As cinzas foram obtidas por calcinação em mufla a $550{ }^{\circ} \mathrm{C}$, por quatro horas, até massa constante, sendo resfriada em dessecador até a temperatura ambiente e pesada (Instituto Adolfo Lutz, 2008).

\subsubsection{Umidade}

Pesou-se $10 \mathrm{~g}$ da amostra fresca em cápsula de porcelana, previamente tarada. $\mathrm{O}$ percentual de umidade foi determinado por meio da secagem em estufa a $105^{\circ} \mathrm{C}$ por 24 horas (Instituto Adolfo Lutz, 2008).

\subsubsection{Nitrogênio e Teor de proteína}

O teor de nitrogênio total das amostras foi determinado pelo Método de Micro-Kjeldahl (Embrapa, 2009), utilizando-se o fator de conversão genérico 6,25 para transformação do teor quantificado de nitrogênio em proteína.

\subsection{Análise estatística}

Os resultados foram submetidos à ANOVA $\mathrm{e}$ comparação de médias pelo teste de Tukey, considerando-se o nível de probabilidade de erro (p) menor que 5\% para determinar a significância, utilizando o software Agroestat versão 1.0 (Barbosa e Maldonado Júnior, 2015).

\section{Resultados e discussão}

Houve efeito significativo $(F=2,63 ; p<0,05)$ para as características avaliadas na couve para o fator supermercados e formas de comercialização (Figura 3). Porém, para variável acidez titulável não houve diferença entre a forma de venda. Para nenhuma das características avaliadas houve interação entre fatores $(F=12,42 ; p=0,078)$ (Figura 3).

A couve apresentou maiores teores de umidade para forma de venda in natura $(88,81 \%)$ e para o supermercado B $(77,75 \%)$ (Figura 3$)$. Observa-se que na couve folha minimamente processada $(67,34 \%)$ o teor de umidade é inferior ao da couve folha in natura $(88,81 \%)$, devido ao fato desta hortaliça ter sofrido rompimento de suas estruturas celulares pelo processamento, o que pode ter ocasionado o extravasamento de água da célula. Hortaliças in natura após colhidas seguem da mesma forma para as gôndolas dos supermercados, evitando rápidas perdas de água pós-colheita, pois o armazenamento refrigerado conserva melhor a umidade.

Hortaliças in natura tendem a ter menor vida em prateleira devido ao elevado teor de água, favorecendo o processo de deterioração e perda de qualidade pós-colheita. Apesar da couve ter apresentado o maior teor de umidade entre as hortaliças analisadas (Figura 3), este encontra-se abaixo de $90,9 \%$ do que é estabelecido pela Taco (2011), inferindo que o produto poderia está há mais tempo exposto a venda.

Maiores teores de cinzas para couve foram para forma de venda in natura $(1,72 \%)$ e para o supermercado B (1,3\%), visto que para forma de venda observou-se um excesso neste teor e o supermercado B esteve dentro do aceitável $(1,3 \%)$ (Figura 3 ). Esse excesso pode ser explicado pelas características inerentes dos genótipos como também época e fertilização adotada.

Os valores obtidos para $\mathrm{pH}$ na couve, apresentou-se ácido $(5,48)$ e próximo a alcalinidade $(6,78 ; 6,15 ; 6,12)$. Contudo, as hortaliças analisadas que apresentaram $\mathrm{pH}$ ácido "supermercado B", característica esta do ponto de vista comercial indesejada, haja vista que a mesma apresenta um sabor levemente amargo que é influenciado pelo pH ácido. Porém, couve com $\mathrm{pH}$ próximos a alcalinidade, $\mathrm{pH} 7$, tendem a ter uma vida de prateleira reduzida, influenciada pelo aumento da atividade enzimática, causando deterioração do produto final. Analisando couve proveniente de cultivo orgânico, Pereira et al. (2015) encontram valores de $\mathrm{pH}$ de 5,56 semelhante aos que foram obtidos nas hortaliças comercializadas no supermercado B. 

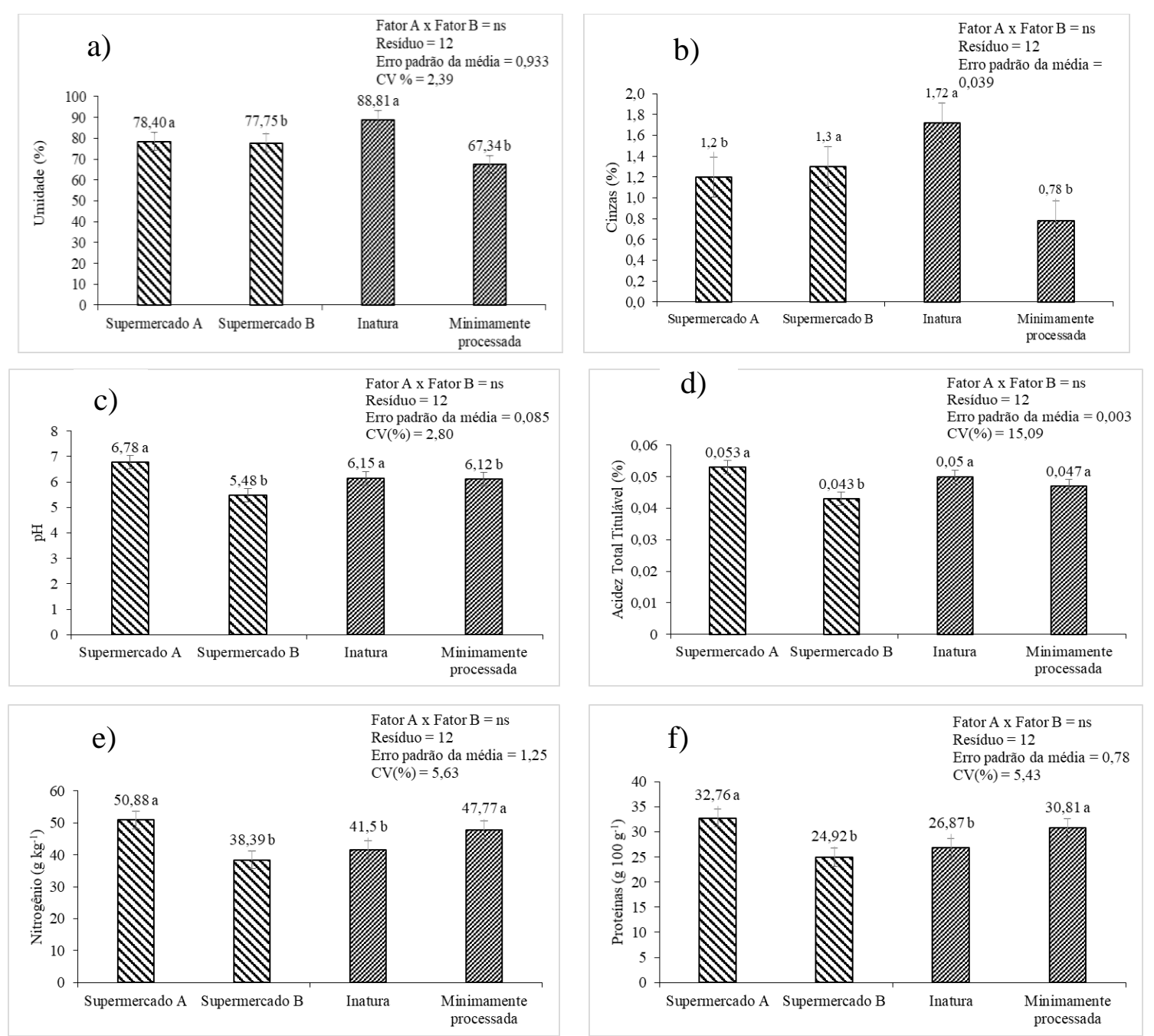

Figura 3 Umidade (a), cinzas (b), pH (c), acidez titulável (d), nitrogênio (e) e proteína (f) para couve in natura e minimamente processada comercializada no município de Jaboticabal - SP. Médias seguidas pela mesma letra, entre supermercados e entre formas de comercialização, não diferem estatisticamente entre si pelo teste de Tukey $(\mathrm{p} \leq 0,05)$.

O maior teor de acidez titulável para couve foi de $0,053 \%(\mathrm{~F}=2,12 ; \mathrm{p}<0,05)$, comercializada no Supermercado B (Figura 3). A forma de comercialização da couve não diferiu estaticamente entre a in natura $0,05 \%$ e a minimamente processada $0,047 \%$, concluindo-se desta maneira que o vegetal foi armazenado sob condições ideais para que esta variável mantivesse essa estabilidade durante esse tempo de armazenamento. Pereira et al. (2015) encontram valores de acidez titulável para hortaliça couve folha de $0,1 \%$, sendo os valores obtidos neste trabalho bem inferiores.

Os teores de nitrogênio na hortaliça folhosa supracitada, variaram de 38,89 g. $\mathrm{kg}^{-1}$ a 50,88 g. $\mathrm{kg}^{-1}$, independentemente do local de comercialização e forma de venda (Figura 3). Os valores obtidos para essa variável encontram-se dentro da faixa ótima para essa hortaliça, 30 a 50 g. $\mathrm{kg}^{-1}$ (Embrapa, 2009). O nitrogênio é considerado um dos nutrientes mais importantes para as hortaliças de uma forma geral, por favorecer maior desenvolvimento da área foliar como também influenciar os teores de proteína.

O teor de proteína seguiu o mesmo padrão para o teor de nitrogênio na cultura da couve (Figura 3). Os valores obtidos encontram-se na

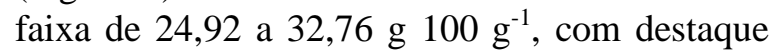
para a forma de venda minimamente processada,

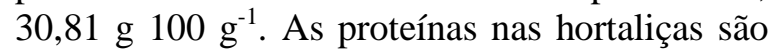


fontes importantes para refeição de milhões de pessoas, especialmente em países em desenvolvimento, devido ao baixo poder aquisitivo ou por não ter acesso a proteína de origem animal (Kinupp e Barros, 2008).
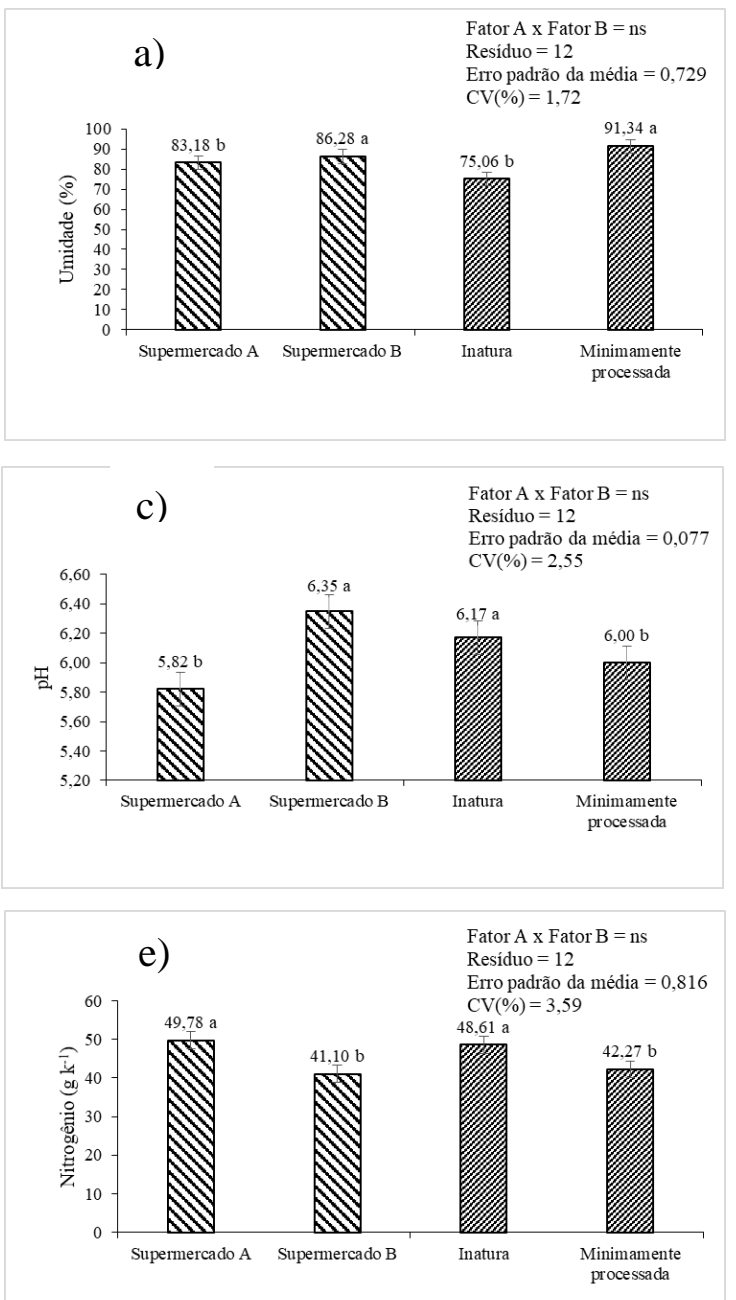

Figura 4 Umidade (a), cinzas (b), pH (c), acidez titulável (d), nitrogênio (e) e proteína (f) para chicória in natura e minimamente processada comercializada em dois supermercados no município de Jaboticabal - SP. Médias seguidas pela mesma letra, entre supermercados e entre formas de comercialização, não diferem estatisticamente entre si pelo teste de Tukey $(\mathrm{p} \leq 0,05)$.

A chicória apresentou maiores teores de umidade para forma de venda minimamente processada, $91,34 \%$ e comercializadas no supermercado B, 86,28\% (Figura 4). O teor de umidade para forma de venda minimamente processada apresentou-se superior a forma de venda in natura devido a embalagem para minimamente processada ter sido realizada no
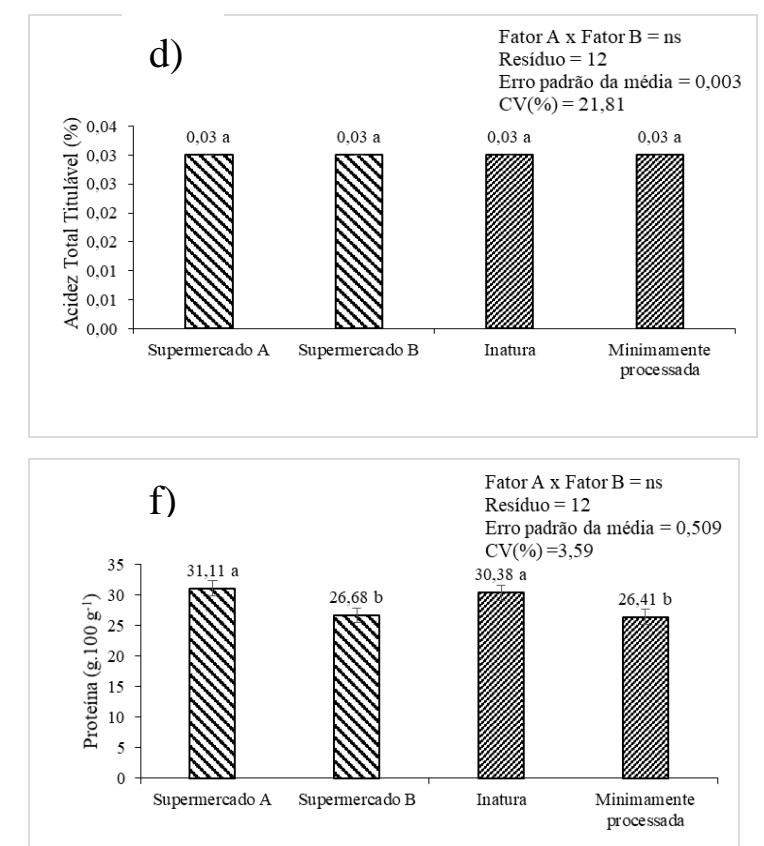

Para as características avaliadas na hortaliça chicória houve efeito significativo $(\mathrm{F}=1,87 ; \mathrm{p}<$ 0,05 ) (Figura 4). Porém para variável cinzas e acidez titulável não houve diferença entre formas de venda e supermercado. Para nenhuma das características avaliadas houve interação entre fatores (Figura 4).
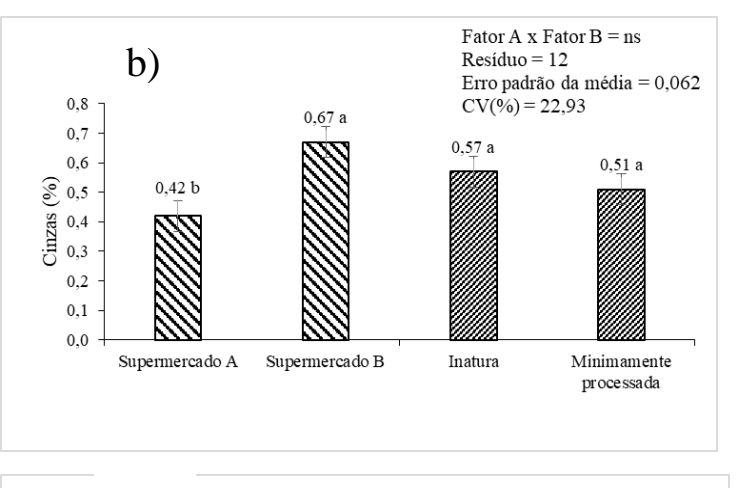

momento da coleta da hortaliça, já que a in natura encontrava-se há mais de três dias exposta para venda, ocorrendo perda por respiração celular, conforme informação obtida em conversa com repositores de mercadoria do supermercado.

Alto teor de cinza foi obtido para o supermercado B, 0,67\% (Figura 4). Esse valor pode ser explicado pelas características inerentes 
a cultivar como também época de plantio e adubação. Menor $\mathrm{pH}$ para chicória foi obtido para o supermercado A, 5,82 (Figura 4). Apesar de ter grande aceitabilidade pelos paulistas, a chicória comercializada no supermercado A, apresentouse ácida quando comparada ao supermercado B. Apesar de altamente nutritiva, esse $\mathrm{pH}$ ácido leva a perda de qualidade da hortaliça, reduzindo assim sua aquisição de compra.

Acidez da chicória, apresentou teores iguais, tanto para os supermercados, $0,03 \mathrm{~g} .100 \mathrm{~g} \mathrm{~g}^{-1}$, como

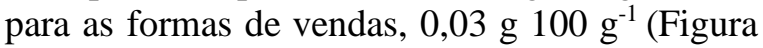
4), indicando que esta hortaliça tinha acabado de ser adquirida pelo supermercado e que as condições de armazenamento favoreceram a preservação da acidez.

O teor de nitrogênio e proteína para chicória apresentaram comportamentos bem semelhantes, em que a chicória obtida no supermercado A apresentou maiores teores, de 49,78 $\mathrm{g} \mathrm{kg}^{-1}$ e 31,11 g $100 \mathrm{~g} \mathrm{~g}^{-1}$, e forma de venda in natura, $48,61 \mathrm{~g} \mathrm{~kg}^{-}$

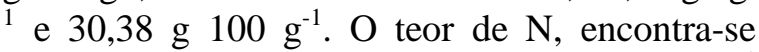
dentro da faixa, citada como ideal, 40 a $50 \mathrm{~g} \mathrm{~kg}^{-1}$ (Embrapa, 2009). A chicória é uma hortaliça altamente proteica quanto comparada a outras hortaliças folhosas como o coentro, cebolinha e espinafre (Taco, 2011).

As variáveis analisadas para o almeirão, apresentaram efeito significativo $(\mathrm{F}=1,59 ; \mathrm{p}<$ $0,05)$ (Figura 5). Porém para o teor de cinzas, não houve diferença entre formas de venda. Para nenhuma das características avaliadas houve interação entre fatores (Figura 5).

A umidade apresentou-se maior no almeirão comercializado no supermercado B, $86,16 \%$ e na forma de minimamente processada, $94,74 \%$. Teor de umidade maior para forma de venda minimamente processada, deve-se ao fato da colheita e o mini processamento ter sido realizada no mesmo dia em que se realizou a compra da hortaliça em ambos os supermercados. A mesma havia sido colhida no período da manhã e ainda mesmo com o desencadeamento da aceleração do processo respiratório, e oxidação apresentou elevado teor de água. As hortaliças de um modo geral apresentam alto teor de água, que com o passar do tempo em armazenamento ocorre a desidratação e perda de qualidades.

$\mathrm{O}$ alto teor de cinza no almeirão, foi obtido para amostras coletadas no supermercado B, $0,68 \%$ e não diferiu entre as formas de vendas (Figura 5). Isso pode ser explicado pela data de aquisição da hortaliça como também ao manejo nutricional que foi adotado no campo. Maiores valores de $\mathrm{pH}$ para a hortaliça foram obtidos nas coletadas no supermercado B, 6,36 e forma de venda in natura, 6,18. Dentro da produção agrícola, deve-se procurar tanto a obtenção de alta produtividade e qualidade pós colheita. $\mathrm{pH}$ muito elevado tende a facilitar o processo de deterioração das hortaliças em função do seu elevado teor de água e aumento da atividade enzimática.

A variável Acidez titulável do almeirão (Figura 5), apresentou-se com teores iguais tanto para os supermercados, $0,03 \mathrm{~g} .100 \mathrm{~g}^{-1}$ como para formas de vendas, $0,03 \mathrm{~g} .100 \mathrm{~g}^{-1}$, indicando que as condições de temperatura no armazenamento e tempo de aquisição do produto favoreceram a sua preservação.

Os teores de nitrogênio e proteína para almeirão apresentaram comportamentos bem semelhantes, em que a hortaliça comercializada no supermercado A, apresentou maiores teores, $48,65 \mathrm{~g} \mathrm{~kg}^{-1} ; 29,98 \mathrm{~g} \mathrm{~kg}^{-1}$ e forma de venda in

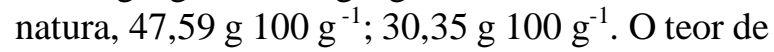
$\mathrm{N}$ encontra-se dentro da faixa do teor ideal estabelecido, 40-50 g. $\mathrm{kg}^{-1}$ (Embrapa, 2009). O almeirão é considerado uma hortaliça de bom teor proteico e relativamente de baixo custo, podendo suprir as necessidades nutricionais do ser humano. 


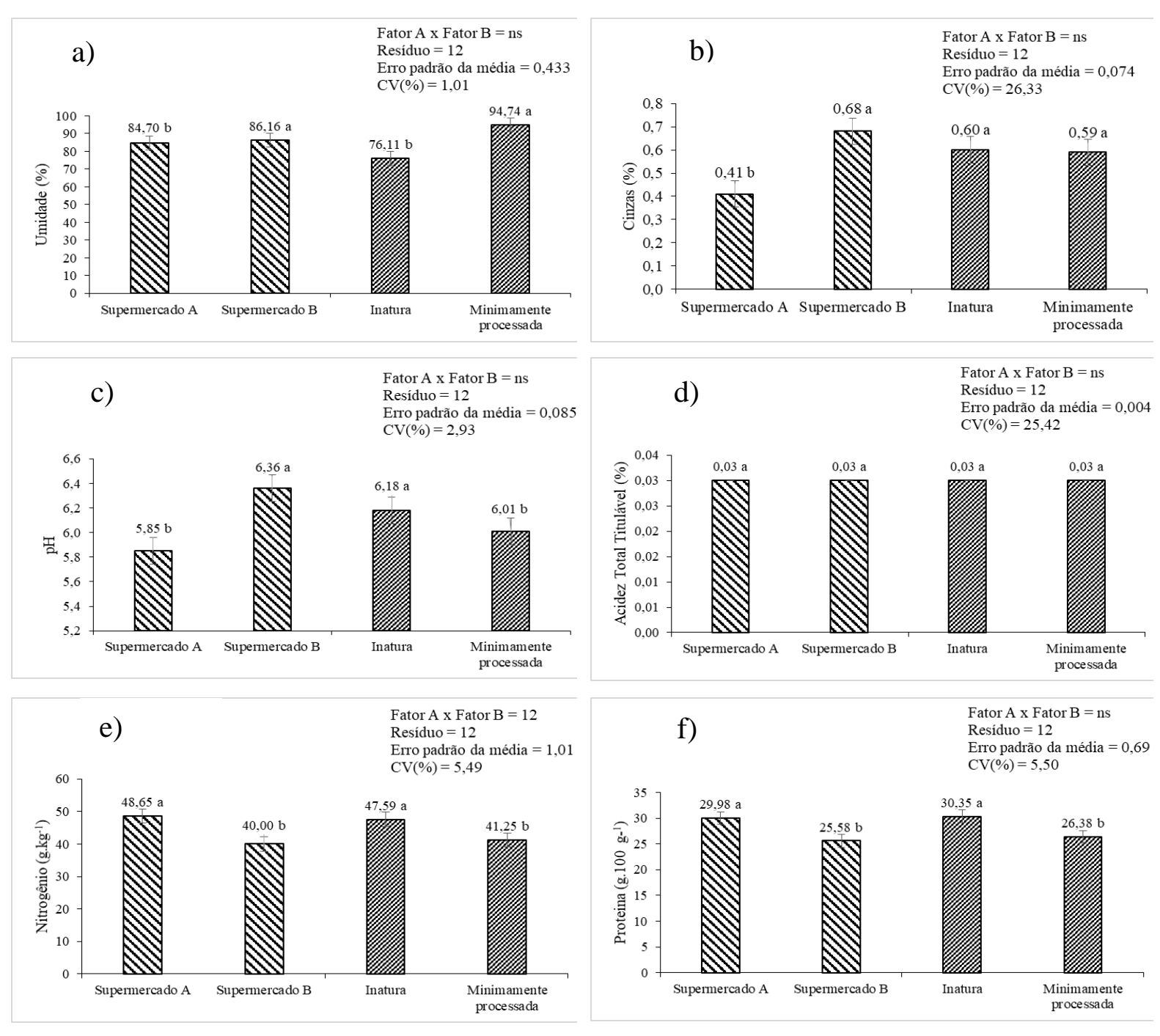

Figura 5 Umidade (a), cinzas (b), pH (c), acidez titulável (d), nitrogênio (e) e proteína (f) para almeirão in natura e minimamente processado comercializado em dois supermercados no município de Jaboticabal - SP. Médias seguidas pela mesma letra, entre supermercados e entre formas de comercialização, não diferem estatisticamente entre si pelo teste de Tukey $(\mathrm{p} \leq 0,05)$.

\section{Conclusão}

As hortaliças folhosas analisadas neste estudo, couve, chicória e almeirão, apresentaram suas qualidades físico-químicas alteradas, conforme a forma de vendas e local de aquisição (supermercados);

O almeirão apresentou maior teor de umidade, seguido da couve e chicória. Os valores de cinzas, acidez titulável, nitrogênio e proteínas das hortaliças estão dentro dos teores considerados satisfatórios com base na Tabela brasileira de composição de alimentos;

Cabe ao consumidor final de hortaliças a tomada de decisão no momento da aquisição de hortaliças, levando em consideração o local e o tipo de comercialização, bem como, a facilidade de compra e o poder aquisitivo;

Entretanto, estudos mais aprofundados sobre o assunto são necessários afim de se traçar o perfil de consumo de hortaliças para o município de Jaboticabal-SP.

\section{Agradecimento}

Os autores agradecem à Coordenação de Aperfeiçoamento de Pessoal de Nível Superior (CAPES - 001) pela concessão da bolsa que auxiliou na realização do presente estudo.

\section{Referências}


Barbosa, J. C; Maldonado Júnior, W. Experimentação agronômica e agroestat Sistemas para análises estatísticas de ensaios agronômicos. Jaboticabal: Multipress Ltda. 2015.

Cenci, A. S. Pesquisa em processamento mínimo de hortaliças no Brasil. In: $2^{\circ}$ Encontro Nacional sobre Processamento Mínimo de Frutas e Hortaliças. Anais... Viçosa: UFV, 110, 2000.

Dalastra, V.; Southier, N.; Moser, C. S.; Dalastra, J.; Lima, C. S. M. Intenção de compra de abacaxi minimamente processado em diferentes cortes. Brazilian Journal of Development, v. 5, n. 7, p. 8975-8982, 2019. https://doi.org/10.34117/bjdv5n7-100

Embrapa. Manual de análises químicas de solos, plantas e fertilizantes. Rio de Janeiro: Embrapa Informação Tecnológica, 1999.

Embrapa. Manual de análises químicas de solos, plantas e fertilizantes. $3^{\mathrm{a}}$ ed. Brasilía, DF: Embrapa Informação Tecnológica, 2009.

Godin, A. Catálogo Brasileiro de Hortaliças: saiba como plantar e aproveitar 50 das espécies mais comercializadas no País. Brasília: SEBRAE e EMBRAPA, 2010, 59 p.

Gonsalves, P. E. Alimentos vegetais e de origem vegetal. Livro dos alimentos. São Paulo: MG Editores, 2009, 4-5 p.

Henrique, V. A; Ferreira, L. P.; Veiga, E. O. B.; Nunes, C. R. Microbiological analysis of basil (Ocimum basilicum L.) marketed in the municipality of Campos dos Goytacazes-RJ. Interdisciplinary Scientific Journal, v. 6, n. 1, p. 120-137, 2019. https://doi.org/10.17115

Instituto Adolfo Lutz. Métodos físico-químicos para análise de alimentos. 4ed, São Paulo: Instituto Adolfo Lutz, 2008, 1020 p.

Kinupp, V. F.; Barros, I. B. I. Teores de proteína e minerais de espécies nativas, potenciais hortaliças e frutas. Ciência e Tecnologia de Alimentos, v. 28, n. 4, p. 846-857, 2008. https://doi.org/10.1590/S0101-20612008000400013

Lefsrud, M.; Kopsell, D.; Wenzel, A.; Sheehan, J. Chances in kale (Brassica oleracea L. var. acephala) carotenoid and chlorophyll pigment concentrations during leaf ontogeny. Scientia Horticultura. v. 112, n. 2, p. 136-141, 2007. https://doi.org/10.1016/ j.scienta.2006.12.026

Pereira, E. M.; Santos, Y. M. G.; Leite Filho, M. T.; Fragoso, S. P.; Pereira, B. B .M. Qualidade pós colheita de frutas e hortaliças cultivadas de forma orgânica. Revista Verde de Agroecologia e Desenvolvimento Sustentável, v. $10, \quad$ n. $2, \quad$ p. $56-60,2015$. https://doi.org/10.18378/rvads.v10i2.3441

Pereira, E. M.; Leite, D. D. F.; Fidelis, V. R. L.; Porto, R. M.; Oliveira, M. I. V.; Magalhães, W. B. Caracterização físico-química de hortaliças tipo folha comercializadas no Brejo Paraibano. Agropecuária Técnica, v. 37, n. 1, p. 19-22, 2016. https://doi.org/0100-7467

Santos, R.B.; Silva, J.M., Silva, C.S.; Nascimento, M.S., Santos, T.M.C.; Costa, J.H.Q. Qualidade microbiológica de alimentos in natura minimamente processados. Global Science and Technology, v. 12, n. 1, p. 43-52, 2019.

Silva, L. C. A. S; Pires, J. A.; Arthur, P. B.; Rossi, R. S., Harder, M. N. C.; Franco, M. A. H.; Franco, L. H., Franco, J. G.; Franco, S. S. H., Franco, C. F. O.; Cazé Filho, J.; Arthur, V. Efeitos da radiação gama na cor e características físicas-químicas de abobrinha Cucurbita moschata minimamente processada. Tecnologia \& Ciência Agropecuária, v. 12, n. 4, p. 47-52, 2018.

Taco/NEPA - Tabela brasileira de composição de alimentos / Núcleo de Estudos e Pesquisas em Alimentação - NEPA - UNICAMP - 4. ed. rev. e ampl. - - Campinas: NEPA - UNICAMP, 2011. $161 \mathrm{p}$.

Vitti, M.C.D.; Kluge, R.A.; Gallo, C.R., Schiavinato, M.A.; Moretti, C.L.; Jacomino, A.P. Aspectos fisiológicos e microbiológicos de beterrabas minimamente processadas. Pesquisa Agropecuária Brasileira, v. 39 n. 10, p. 10271032, 2004. https://doi.org/10.1590/S0100204X2004001000011 